\title{
Susceptibility to insecticides and resistance mechanisms in three populations of Aedes aegypti from Peru
}

Jesus Pinto ${ }^{1}$, Miriam Palomino ${ }^{1}$, Leonardo Mendoza-Uribe' ${ }^{1}$, Carmen Sinti ${ }^{2}$, Kelly A. Liebman ${ }^{3,4}$

and Audrey Lenhart ${ }^{4^{*}}$ (D)

\begin{abstract}
Background: Epidemics of dengue, chikungunya and Zika are a growing threat to areas where Aedes aegypti are present. The efficacy of chemical control of Ae. aegypti is threatened by the increasing frequency of insecticide resistance. The objective of this study was to determine the susceptibility status as well as the biochemical and molecular mechanisms underlying insecticide resistance in three populations of Ae. aegypti in high risk areas of dengue, chikungunya, and Zika in Peru.
\end{abstract}

Methods: Bioassays were conducted on adult Ae. aegypti to evaluate their susceptibility to insecticides used currently or historically for mosquito control in Peru, including six pyrethroids, three organophosphates and one organochlorine, in populations of Ae. aegypti from the districts of Chosica (Department of Lima), Punchana (Department of Loreto) and Piura (Department of Piura). Resistance mechanisms were determined by biochemical assays to assess activity levels of key detoxification enzyme groups (nonspecific esterases, multi-function oxidases, glutathione S-transferases and insensitive acetylcholinesterase). Real-time PCR assays were used to detect two kdr mutations (V1016l and F1534C) on the voltage-gated sodium channel gene.

Results: Resistance to DDT was detected in all three populations, and resistance to pyrethroids was detected in all populations except the population from Chosica, which still exhibited susceptibility to deltamethrin. Resistance to organophosphates was also detected, with the exception of populations from Punchana and Piura, which still demonstrated susceptibility to malathion. In general, no increase or alteration of activity of any enzyme group was detected. Both $1016 \mathrm{l}$ and 1534C alleles were detected in Punchana and Piura, while only the 1534C allele was detected in Chosica.

Conclusions: The results suggest that resistance to multiple classes of insecticides exist in areas important to Ae. aegypti-borne disease transmission in Peru. The F1534C mutation was present in all 3 populations and the V1016 mutation was present in 2 populations. To our knowledge, this is the first report of the presence of $1016 \mathrm{l}$ and $1534 \mathrm{C}$ in Ae. aegypti in Peru. The absence of highly elevated enzymatic activity suggests that target site resistance is a key mechanism underlying insecticide resistance in these populations, although further research is needed to fully understand the role of metabolic resistance mechanisms in these populations.

Keywords: Aedes aegypti, Insecticide resistance, Peru

\footnotetext{
*Correspondence: AJL8@cdc.gov

${ }^{4}$ Centers for Disease Control and Prevention, Atlanta, GA, USA

Full list of author information is available at the end of the article
} 


\section{Background}

Dengue is of increasing public health concern globally. An estimated 2.5 billion people, representing $40 \%$ of the world's human population, live in areas at risk of dengue transmission and there are an estimated 390 million cases of dengue per year in tropical and subtropical areas [1]. In tropical and subtropical urban areas, the mosquito Aedes aegypti is the main vector of dengue, chikungunya and Zika viruses. In 1947, the Ae. aegypti eradication programme in the Americas began, which managed to eliminate this vector in 19 countries in the region, relying heavily on the widespread application of the organochlorine insecticide DDT [2,3]. However, the decline of this programme at the end of the 1960s led to broad Ae. aegypti reinfestations originating from areas that had not succeeded in fully eliminating it [4].

Aedes aegypti was first reported in Peru in 1852 and is believed to have entered from the north via Guayaquil, Ecuador, progressively establishing itself along the north and central Peruvian coast, eventually extending its distribution to Tacna in the far south [5]. Aedes aegypti was eliminated from Peru in 1958 but was subsequently reintroduced and detected in 1984 in Loreto and Ucayalí, and then dispersed to neighboring regions including San Martín and the central jungle (Satipo and Chanchamayo). In 1990, an explosive epidemic of dengue (caused by DENV-1) occurred in several key cities in the Peruvian Amazon, and at present, almost all areas of the country where Ae. aegypti are present report cases of dengue, with the circulation of all four dengue serotypes now documented in Peru [6]. Aedes aegypti is now widely dispersed in 20 departments nationwide and has been detected in 486 districts, resulting in over 14 million people at risk of contracting Ae. aegypti-borne illnesses [7].

The integrated control of Ae. aegypti in Peru is based principally on the use of insecticides to reduce the populations of larvae and adults. The reduction of larval populations has historically been based on the application of the organophosphate insecticide temephos to larval habitats. To reduce adult mosquito populations, the pyrethroid insecticides cyfluthrin, alpha-cypermethrin, deltamethrin, lambda-cyhalothrin and cypermethrin had been used up until 2014, when this study was conducted.

Insecticide resistance in mosquitoes can be caused by increased activity of enzymes that detoxify insecticides ('metabolic resistance'), alterations at the target site of the insecticides in the mosquito ('target site resistance'), thickening of the cuticle to inhibit insecticide penetration, and the development of behaviors that lead to the mosquito avoiding contact with insecticides. Metabolic resistance typically involves the increased activity of any of the three main groups of detoxification enzymes: carboxylesterases, multi-function oxidases (MFOs), and glutathione S-transferases (GSTs) [8]. Target site resistance in mosquitoes often involves alterations that render acetylcholinesterase insensitive or conformational changes on the voltage-gated sodium channel that prevent insecticide binding and thus prevents the mosquito from being knocked down after exposure (resulting in knockdown resistance, $k d r)[9,10] . K d r$ is associated with resistance to both the organochlorine insecticide DDT and pyrethroid insecticides, and results from non-synonymous point mutations on the gene that codes for the voltage-gated sodium channel [10]. Pyrethroid insecticides act at the level of the voltage-gated sodium channel (VGSC), which is a transmembrane protein that is made up of four homologous domains (I-IV), with each domain consisting of six hydrophobic segments (S1-S6) [11]. Several mutations have been identified at different positions on the VGSC in Ae. aegypti (V410L, S989P, I1011M/V, V1016G/I, F1269C, F1534C) [12-15], with V1016I/G and F1534C occurring on IIS6 and IIIS6, respectively, clearly associated with pyrethroid resistance $[13,16]$.

Widespread vector control for malaria in Peru began in the 1960s with the use of DDT. Organophosphates (fenitrothion and chlorpyrifos) were also used in the 1980 s, and in the 1990s pyrethroid use became common (cyfluthrin, alpha-cypermethrin, cypermethrin and lambda-cyhalothrin) [17]; during this same period, dengue vector control activities were first started. Deltamethrin was first used for Ae. aegypti control in 2000. National surveillance data from Peru's National Institute of Health shows that insecticide resistance in Ae. aegypti was first detected in 2005 in the departments of Tumbes (to permethrin, propoxur and carbaryl) and La Libertad (to propoxur and bendiocarb). In 2011, resistance to alpha-cypermethrin was reported in the department of Madre de Dios and deltamethrin resistance was detected in the department of Piura. Although routine resistance monitoring is carried out by Peru's National Institute of Health, very little is known about the underlying mechanisms driving the resistance. The objective of the present study was to link susceptibility status with biochemical and molecular mechanisms involved in resistance in key populations of Ae. aegypti from three departments in Peru.

\section{Methods \\ Study areas}

The study was conducted in three departments in Peru (Lima, Loreto and Piura) that represent two ecological regions of the country: the coast and the Amazon. The Peruvian coastline is formed by a desert strip that extends from north to south and borders the Pacific Ocean to the west and is divided into three zones: the north coast that borders Ecuador (where the 
department of Piura is located); the central coast where the department of Lima is located; and the south coast that runs to the border with Chile. The department of Loreto is located in the Amazon region of central Peru (Fig. 1).

In Lima department, the city of Chosica $\left(11^{\circ} 56^{\prime} 41^{\prime \prime} \mathrm{S}\right.$, $\left.76^{\circ} 41^{\prime} 44.7^{\prime \prime} \mathrm{W}\right)$ was selected, with a population of 218,976 inhabitants [18] and an area of $236.5 \mathrm{~km}^{2}$. The city of Lima (capital of Lima department and capital of Peru) experienced an outbreak of dengue in 2005, with 440 cases [6]. This outbreak was of particular interest because until that time, Ae. aegypti had not been commonly reported in Lima. In Piura, the districts of Piura and Castilla $\left(5^{\circ} 14^{\prime} 56.2^{\prime \prime} \mathrm{S}, 80^{\circ} 37^{\prime} 32.9^{\prime \prime} \mathrm{W}\right)$ were selected; together these districts have 459,176 inhabitants [18] and an area of $992.5 \mathrm{~km}^{2}$. Since the 1990s, Piura has experienced endemic dengue transmission, with a large outbreak occurring in 2001 with 11,713 cases. In Loreto, the Punchana district of the city of Iquitos was selected $\left(3^{\circ} 42^{\prime} 13.1^{\prime \prime} \mathrm{S}, 73^{\circ} 14^{\prime} 57^{\prime \prime} \mathrm{W}\right)$ which has 69,068 inhabitants [18] and an area of $1,573.4 \mathrm{~km}^{2}$. The city of Iquitos has also experienced endemic dengue transmission for more than two decades, and in 2011, experienced a large and severe outbreak with 21,245 cases and 19 deaths [19].

\section{Entomological collections}

Between February and August of 2014, a cross-sectional entomological survey was conducted using oviposition traps ('ovitraps') that consisted of $500 \mathrm{ml}$ water-holding cups lined with a strip of filter paper as an oviposition substrate. The ovitraps were distributed every 5 blocks in both residential and non-residential sites throughout the sampling area. Data on temperature, humidity and the coordinates of each ovitrap were recorded. The ovitraps were left in situ for up to three weeks and then collected. The ovitrap papers were transferred to the National Entomology Reference Laboratory at Peru's National Institute of Health (INS), Lima, for egg detection and positive papers were placed in a humid chamber for 7 days, to favor their maturation. The papers were stored at $25^{\circ} \mathrm{C}$ and $70 \%$ humidity for no more than three months before hatching. The paper strips containing the eggs were immersed in water to allow the larvae to hatch (generation $\mathrm{F}_{0}$ ). The larvae and resulting adults were reared and

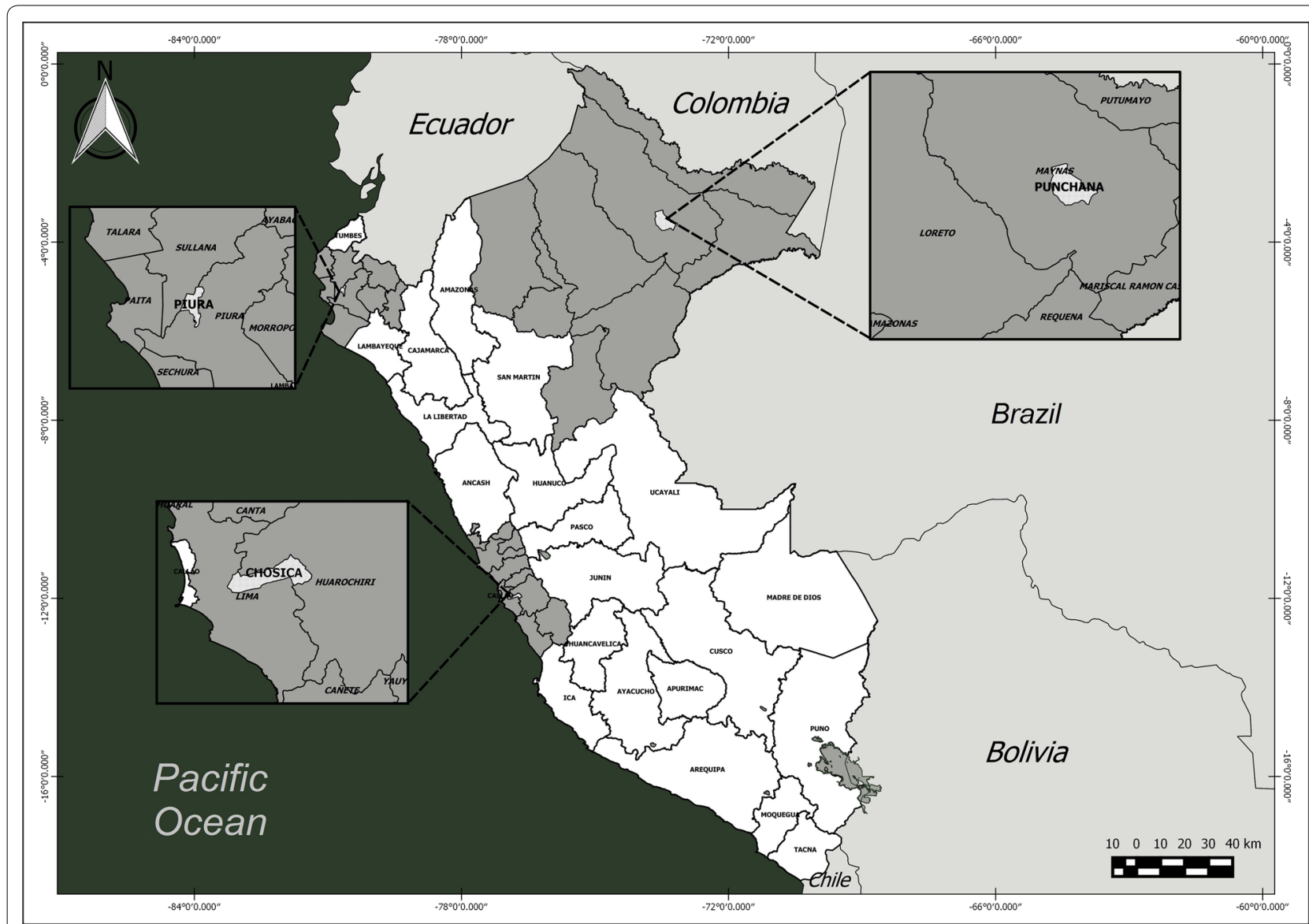

Fig. 1 Map of Peru, showing the sites where Aedes aegypti eggs were collected 
bred under controlled conditions of humidity $(80 \pm 10 \%$ $\mathrm{RH})$ and temperature $\left(27 \pm 1{ }^{\circ} \mathrm{C}\right)$ in the insectary of the INS National Entomology Reference Laboratory, Lima, Peru. All bioassays, biochemical and molecular tests were conducted using $F_{1}$ progeny of the generation that emerged from the original field-collected eggs.

\section{Insecticide bioassays}

For adult mosquito bioassays, insecticides chosen were those used over the past 20 years in Peru for vector control, including DDT, organophosphates, carbamates and pyrethroids. Bioassays were performed following the standard protocol developed by the WHO [20], in which mosquitoes were exposed to insecticide-impregnated papers (University of Malaysia Vector Control Research Unit, Universiti Sains Malaysia). An average of 300 unfed female mosquitoes aged 3 to 5 days-old from each population were evaluated for susceptibility to each insecticide. In addition, an average of 100 mosquitoes from the Rockefeller susceptible strain were evaluated simultaneously with each of the populations and for each insecticide, to verify the insecticidal effects of the impregnated papers. Mosquitoes were exposed for $1 \mathrm{~h}$ to papers treated with alpha-cypermethrin (0.05\%), cypermethrin $(0.05 \%)$, deltamethrin $(0.05 \%)$, etofenprox $(0.5 \%)$, lambda-cyhalothrin $(0.05 \%)$, permethrin $(0.75 \%)$, DDT (4\%), malathion (5\%) and pirimiphos-methyl (0.25\%), and exposed for $2 \mathrm{~h}$ to papers treated with fenitrothion (1\%). Negative controls were also included in which mosquitoes were exposed to papers impregnated with solvents only. Following exposure, mosquitoes were transferred to holding tubes and provided with $10 \%$ sugar solution. Mortality was recorded at $24 \mathrm{~h}$ post-exposure. All bioassays were performed in the INS National Entomology Reference Laboratory.

\section{Biochemical tests}

All biochemical analyses were performed based on Centers for Disease Control and Prevention (CDC) protocols [21]. An average of 120 adult females per field population and 120 adult females from the Rockefeller susceptible strain aged 3 to 5 days were killed by freezing and stored at $-20{ }^{\circ} \mathrm{C}$ for a maximum of two months prior to processing. The head and thorax of each mosquito were separated from the abdomen and homogenized in $100 \mu \mathrm{l}$ of potassium phosphate $\left(\mathrm{KPO}_{4}\right)$ buffer $(6.6 \mathrm{~g}$ of dibasic potassium phosphate $/ 1.7 \mathrm{~g}$ of monobasic phosphate/100 $\mathrm{ml}$ of distilled water, $\mathrm{pH}$ 7.2). The homogenate was diluted to $1 \mathrm{ml}$ using the same buffer.

A volume of $100 \mu \mathrm{l}$ of homogenate was evaluated in triplicate for each mosquito. Homogenates were transferred to a 96-well flat bottom microplate, with 30 mosquitoes analyzed in triplicate per plate. The Rockefeller strain was used as the susceptible reference population in all biochemical analyses. The enzyme groups evaluated were: beta-type non-specific esterases (NSEs), MFOs, GSTs, and insensitive or modified acetylcholinesterase (MACE) [22-24]. The substrates used in each assay included: $\beta$-naphthyl acetate for NSE, reduced glutathione and CDNB (1-chloro-2,4'-dinitrobenzene) for GSTs, and TMBZ (3,3', 5,5'-tetramethylbenzidine dihydrochloride) for MFO. Acetylthiocholine iodide as well as the carbamate insecticide propoxur were used to measure acetylcholinesterase insensitivity. The positive controls consisted of cytochrome $\mathrm{C}$ for MFO and $\beta$-naphthol for NSE and were run in triplicate on the corresponding plates, and the three negative controls per plate consisted of the potassium phosphate buffer. The total protein concentration for each mosquito was determined using the methodology described by Brogdon [25, 26]. This allowed for the detection of differences in the body masses of the mosquitoes, which was used as a correction factor for the enzymatic analyses. Absorbances were measured by spectrophotometry using a microplate reader (Multiskan GO, Thermo Fisher Scientific, Hampton, NH, USA), at the wavelengths indicated for each enzyme family (540 nm for NSE, $620 \mathrm{~nm}$ for MFO and protein, $340 \mathrm{~nm}$ for GST, and $414 \mathrm{~nm}$ for MACE).

\section{Molecular analyses}

Molecular analyses were performed on mosquitoes surviving the bioassays with pyrethroids and DDT, to screen for the presence of the $k d r$ mutations V1016I and F1534C. DNA was extracted from individual mosquitoes by placing each adult mosquito in a PCR tube containing $50 \mu \mathrm{l}$ of a 1:10 dilution of $10 \times$ buffer (Promega, Madison, WI, USA) containing $15 \mathrm{mM} \mathrm{MgCl}, 50 \mathrm{mM} \mathrm{KCl}$, and $10 \mathrm{mM}$ Tris- $\mathrm{HCl}\left(\mathrm{pH} 9.0\right.$ at $\left.25^{\circ} \mathrm{C}\right)$. The tubes were incubated at $95^{\circ} \mathrm{C}$ for $10 \mathrm{~min}$. The resulting DNA was stored at $-20^{\circ} \mathrm{C}$ until PCR analysis.

DNA was analyzed by real-time PCR followed by a melting curve analysis based on the methodologies described by Saavedra-Rodriguez et al. [13] and Yanola et al. [27]; primer sequences are presented in Table 1. The PCR for the V1016I mutation was carried out in a total reaction volume of $20 \mu \mathrm{l}$ using $2 \mu \mathrm{l}$ of DNA template, $8 \mu \mathrm{l}$ of SuperMix Green SYBR ${ }^{\circledR}$ Perfecta $2 \times$ (which contains a mixture of dNTPs, $\mathrm{MgCl}_{2}$, AccuStart Taq DNA polymerase, SybrGreen), $0.2 \mu \mathrm{M}$ of the common primer Ile1016r and $0.2 \mu \mathrm{M}$ and $0.17 \mu \mathrm{M}$ of the specific primers Ile1016f and Val1016f, respectively. The cycling conditions were: $95{ }^{\circ} \mathrm{C}$ for 3 min followed by 35 cycles of $95{ }^{\circ} \mathrm{C}$ for $10 \mathrm{~s}$, $60{ }^{\circ} \mathrm{C}$ for $10 \mathrm{~s}$ and $72{ }^{\circ} \mathrm{C}$ for $30 \mathrm{~s}$, and a final extension step of $95^{\circ} \mathrm{C}$ for $10 \mathrm{~s}$. The melting curve was determined using a gradient from $65{ }^{\circ} \mathrm{C}$ to $95{ }^{\circ} \mathrm{C}$ with an increase of $0.2^{\circ} \mathrm{C}$ every $10 \mathrm{~s}$, where a single peak at $76{ }^{\circ} \mathrm{C}$ corresponded to 
Table 1 Primer sequences for real-time PCR detection of $k d r$ mutations V1016l and F1534C

\begin{tabular}{|c|c|}
\hline Primer & Primer sequence $\left(5^{\prime}-3^{\prime}\right)$ \\
\hline Val1016f & $\begin{array}{l}\text { GCGGGCGGCGGGGGCGGGGCCACAAAT } \\
\text { TGTTTCCCACCCGCACCGG }\end{array}$ \\
\hline Ile1016f & GCGGGCACAAATTGTTTCCCACCCGCACTGA \\
\hline Ile1016r & TGATGAACCSGAATTGGACAAAAGC \\
\hline Cys1534+f & $\begin{array}{l}\text { GCGGGCAGGGCGGCGGGGGCGGGGCCT } \\
\text { CTACTTTGTGTTCTTCATCATGTG }\end{array}$ \\
\hline Phe1534+f & GCGGGCTCTACTTTGTGTTCTTCATCATATT \\
\hline Phe1534+r & TCTGCTCGTTGAAGTTGTCGAT \\
\hline
\end{tabular}

a mutant homozygote (I1016/I1016), peaks at both $76{ }^{\circ} \mathrm{C}$ and $83^{\circ} \mathrm{C}$ corresponded to a heterozygote (V1016/I1016) and a single peak at $83{ }^{\circ} \mathrm{C}$ corresponded to a wild type homozygote (V1016/V1016). The PCR for the F1534C mutation was carried out in a total reaction volume of $20 \mu \mathrm{l}$ using $2 \mu \mathrm{l}$ of DNA template, $9 \mu \mathrm{l}$ of PerfeCTa SYBR Green SuperMix (Quantabio, Beverly, MA, USA), $0.3 \mu \mathrm{M}$ of the common primer Phe1534+r and $0.3 \mu \mathrm{M}$ and $0.325 \mu \mathrm{M}$ of the specific primers Phe1534+f and Cys1534+f, respectively. The cycling conditions were: $95{ }^{\circ} \mathrm{C}$ for 3 min followed by 37 cycles of $95^{\circ} \mathrm{C}$ for $10 \mathrm{~s}$, $57^{\circ} \mathrm{C}$ for $30 \mathrm{~s}$ and $72{ }^{\circ} \mathrm{C}$ for $30 \mathrm{~s}$, and a final extension at $95{ }^{\circ} \mathrm{C}$ for $10 \mathrm{~s}$. The melting curve was determined using a gradient from $65{ }^{\circ} \mathrm{C}$ to $95{ }^{\circ} \mathrm{C}$ with an increase of $0.5^{\circ} \mathrm{C}$ every $5 \mathrm{~s}$, where a single peak at $82{ }^{\circ} \mathrm{C}$ corresponded to a mutant homozygote (C1534/C1534), peaks at both $78{ }^{\circ} \mathrm{C}$ and $82{ }^{\circ} \mathrm{C}$ corresponded to a heterozygote (F1534/ C1534) and a single peak at $78{ }^{\circ} \mathrm{C}$ corresponded to a wild type homozygote (F1534/F1534). The amplification and melting curve analysis were performed using a Bio-Rad CFX96 real time PCR system (Bio-Rad, Hercules, CA, USA). DNA from of Ae. aegypti individuals from the Rockefeller strain served as a wild-type control, while DNA from previously genotyped individuals was used for positive controls for the $k d r$ mutations.

\section{Data analysis}

The results of the bioassays were interpreted based on the percent mortality at $24 \mathrm{~h}$ post-exposure to each insecticide, using the criteria recommended by WHO: $98-100 \%$ mortality indicates susceptibility; 90-97\% mortality suggests that resistance may be developing; and $<90 \%$ mortality indicates the presence of resistance [20].

For the biochemical analyses, mean absorbance, standard deviations and coefficients of variation were calculated based on the data from the three replicates of each mosquito. Samples with a coefficient of variation higher than 0.10 were not included in the analyses. The mean absorbance of the negative control was subtracted from the value of each sample for each enzyme to eliminate background noise. Corrections were performed using the total protein values because there were significant differences in body size among the individuals. Cut-off values for each enzyme group were determined using the values obtained from the Rockefeller susceptible reference strain of Ae. aegypti by adding the average of the optical density results to twice the standard deviation of the replicates. Averages of the optical densities of the field populations greater than this cut-off value were considered elevated for the enzyme group in question. In addition, the average absorbances of each population for each of the enzyme groups were analyzed to determine whether they reflected a normal distribution using the Shapiro-Wilk test. To determine the differences in enzymatic activity in each population, the enzymatic activity profiles of each population were compared with the Rockefeller strain using the Kruskall-Wallis non-parametric test.

The allelic frequencies for $1016 \mathrm{I}$ and $1534 \mathrm{C}$ were calculated using the following equation:

$$
\frac{\text { No. of heterozygotes }+2 \text { (No. of homozygotes })}{2(\text { Total no. of mosquitoes analyzed })}
$$

\section{Results}

Insecticide bioassays

A total of 1724 eggs were collected from the field in Chosica, 2122 eggs in Punchana and 899 eggs in Piura. Bioassays were conducted using Ae. aegypti $\mathrm{F}_{1}$ progeny from Chosica $(n=2693)$, Punchana $(n=2702)$ and Piura $(n=2396)$. Table 2 and Fig. 2 show the average percentages of mortality for the insecticides tested for all three populations. Mortality results from the Chosica population revealed: (i) resistance to alpha-cypermethrin, cypermethrin, etofenprox, DDT, fenitrothion and pirimiphos-methyl; (ii) developing resistance to lambda-cyhalothrin and malathion, and (iii) susceptibility to deltamethrin. The Punchana and Piura populations showed resistance to all evaluated insecticides with the exception of malathion. Mortality in the controls was always less than 5\%, so Abbott's formula for corrected mortality was not applied.

\section{Biochemical tests}

The distribution of absorbances reflecting the levels of enzymatic activity detected in the three populations of Ae. aegypti, compared to the Rockefeller reference strain is shown in Fig. 3. In general, no increased or altered of activity of any enzyme group was detected since the absorbance averages were below their cutoff values. However, it should be noted that while the population from Piura presented an overall average absorbance below the cut-off value for MFO (average 
Table 2 Results of bioassays conducted on Peruvian Aedes aegypti

\begin{tabular}{|c|c|c|c|c|c|}
\hline Insecticide & Population & No. tested & $\%$ Mortality $^{a}$ & $95 \% \mathrm{Cl}$ & $\begin{array}{l}\text { Resistance } \\
\text { status }\end{array}$ \\
\hline \multirow[t]{3}{*}{ DDT } & Chosica & 299 & 0 & - & R \\
\hline & Punchana & 300 & 0 & - & $\mathrm{R}$ \\
\hline & Piura & 301 & $13.3 \pm 9.2$ & $7.4-19.1$ & $\mathrm{R}$ \\
\hline \multirow[t]{3}{*}{ Deltamethrin } & Chosica & 294 & $99.3 \pm 1.6$ & $98.3-100.3$ & S \\
\hline & Punchana & 298 & $51.3 \pm 2.9$ & $43.2-59.6$ & $\mathrm{R}$ \\
\hline & Piura & 604 & $74.7 \pm 0.4$ & $70.2-79$ & $\mathrm{R}$ \\
\hline \multirow[t]{3}{*}{ Cypermethrin } & Chosica & 301 & $52.2 \pm 0.1$ & $39.8-65.3$ & $\mathrm{R}$ \\
\hline & Punchana & 302 & $2.3 \pm 2.7$ & $0.6-4.0$ & $\mathrm{R}$ \\
\hline & Piura & nt & nt & - & nt \\
\hline \multirow[t]{3}{*}{ Alpha-cypermethrin } & Chosica & 308 & $72.4 \pm 3.4$ & $63.6-80.6$ & $\mathrm{R}$ \\
\hline & Punchana & 295 & $4.7 \pm 5.0$ & $1.6-8.0$ & $\mathrm{R}$ \\
\hline & Piura & $\mathrm{nt}$ & $\mathrm{nt}$ & - & $\mathrm{nt}$ \\
\hline \multirow[t]{3}{*}{ Lambda-cyhalothrin } & Chosica & 290 & $96.9 \pm 5.2$ & $93.6-100.2$ & RV \\
\hline & Punchana & 301 & $24.3 \pm 5.5$ & $20.8-27.8$ & $\mathrm{R}$ \\
\hline & Piura & $\mathrm{nt}$ & nt & - & $\mathrm{nt}$ \\
\hline \multirow[t]{3}{*}{ Etofenprox } & Chosica & 302 & $8.3 \pm 10.3$ & $1.7-14.8$ & $\mathrm{R}$ \\
\hline & Punchana & 300 & $0.3 \pm 1.2$ & $-0.4-1.1$ & $\mathrm{R}$ \\
\hline & Piura & $\mathrm{nt}$ & $\mathrm{nt}$ & - & $\mathrm{nt}$ \\
\hline \multirow[t]{3}{*}{ Permethrin } & Chosica & $\mathrm{nt}$ & $\mathrm{nt}$ & - & $\mathrm{nt}$ \\
\hline & Punchana & $\mathrm{nt}$ & $\mathrm{nt}$ & - & $\mathrm{nt}$ \\
\hline & Piura & 302 & $12.9 \pm 6.3$ & $8.9-16.9$ & $R$ \\
\hline \multirow[t]{3}{*}{ Malathion } & Chosica & 301 & $94.7 \pm 4.3$ & $92-97.4$ & RV \\
\hline & Punchana & 304 & $99.0 \pm 1.8$ & $97.9-100.1$ & S \\
\hline & Piura & 586 & $98.8 \pm 2.2$ & $97.8-99.7$ & S \\
\hline \multirow[t]{3}{*}{ Fenitrothion } & Chosica & 303 & $36.6 \pm 7.9$ & $31.7-41.7$ & $\mathrm{R}$ \\
\hline & Punchana & 301 & $9.0 \pm 6.9$ & $4.7-13.5$ & $\mathrm{R}$ \\
\hline & Piura & 309 & $5.8 \pm 5.0$ & $2.8-9.1$ & $\mathrm{R}$ \\
\hline \multirow[t]{3}{*}{ Pirimiphos-methyl } & Chosica & 295 & $84.1 \pm 7.1$ & $79.57-8.54$ & $\mathrm{R}$ \\
\hline & Punchana & 301 & $2.3 \pm 2.7$ & $0.6-4.0$ & $\mathrm{R}$ \\
\hline & Piura & 294 & $39.5 \pm 9.2$ & $33.7-45.4$ & $\mathrm{R}$ \\
\hline
\end{tabular}

a Values are the mean \pm SD. A minimum of three assays were performed per insecticide at each site

Abbreviations: $\mathrm{Cl}$, confidence interval; $\mathrm{nt}$, not tested; $\mathrm{R}$, resistant; $\mathrm{S}$, susceptible; $\mathrm{RV}$, resistance to be verified

absorbance $=0.0202$; cut-off $=0.0243$ ), a notable proportion (18\%) of individuals showed increased levels of activity of these enzymes. Similarly, the populations from Chosica and Piura showed overall average absorbances for GSTs that were below the cut-off value (average absorbances $=0.0062$ and 0.0077 , respectively; cut-off $=0.0085)$, yet showed elevated GST activity in a sizable proportion of individuals (18\% and $38 \%$, respectively).

\section{Molecular analyses}

In the survivors of the DDT and pyrethroid bioassays, the $k d r$ alleles $1016 \mathrm{I}$ and $1534 \mathrm{C}$ were present with overall frequencies of 0.42 and 0.84 , respectively. The V1016I mutation was only detected in the populations from
Punchana and Piura, with allele frequencies ranging from 0.42 to 0.72 (Table 3). The F1534C mutation was detected in all three populations with allele frequencies ranging from 0.47 to 1.0, with the homozygous mutant genotype predominating in the Punchana and Piura populations (Table 4). When comparing across the survivors of exposure to different insecticides, no differences in allele frequencies were detected based on insecticide type.

\section{Discussion}

Since 1995, the INS National Entomology Reference Laboratory and its network of regional laboratories have been monitoring insecticide resistance in various species of Anopheles and Ae. aegypti. In Anopheles albimanus, evidence of widespread resistance to insecticides 
a

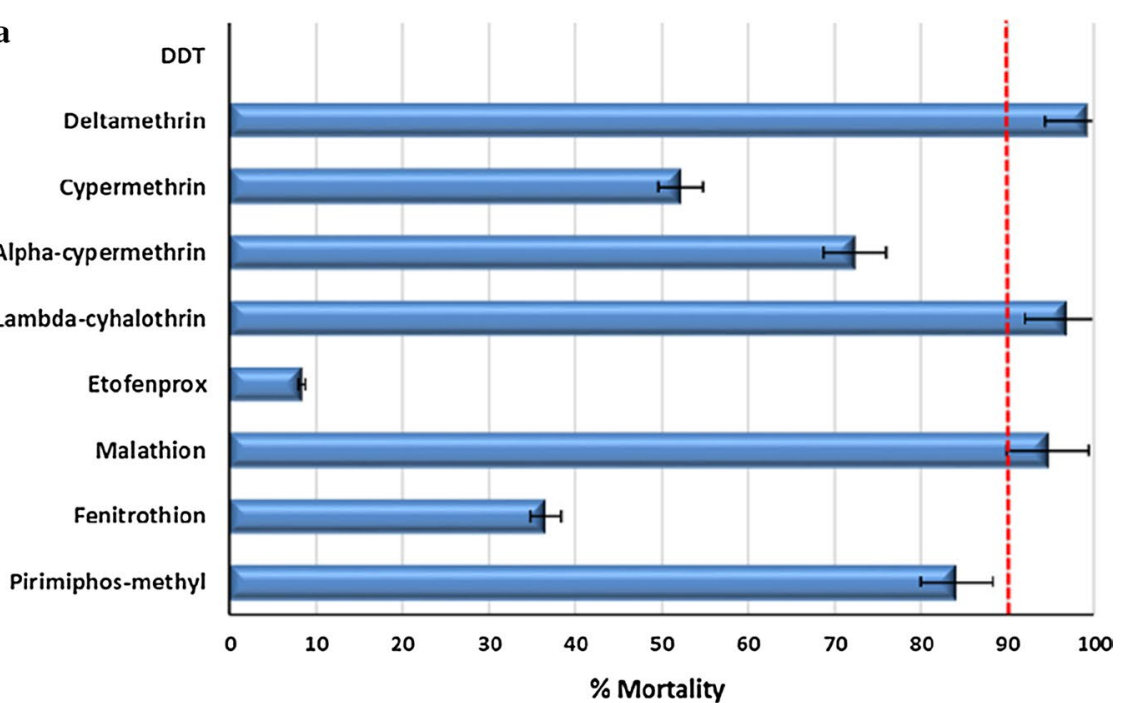

b

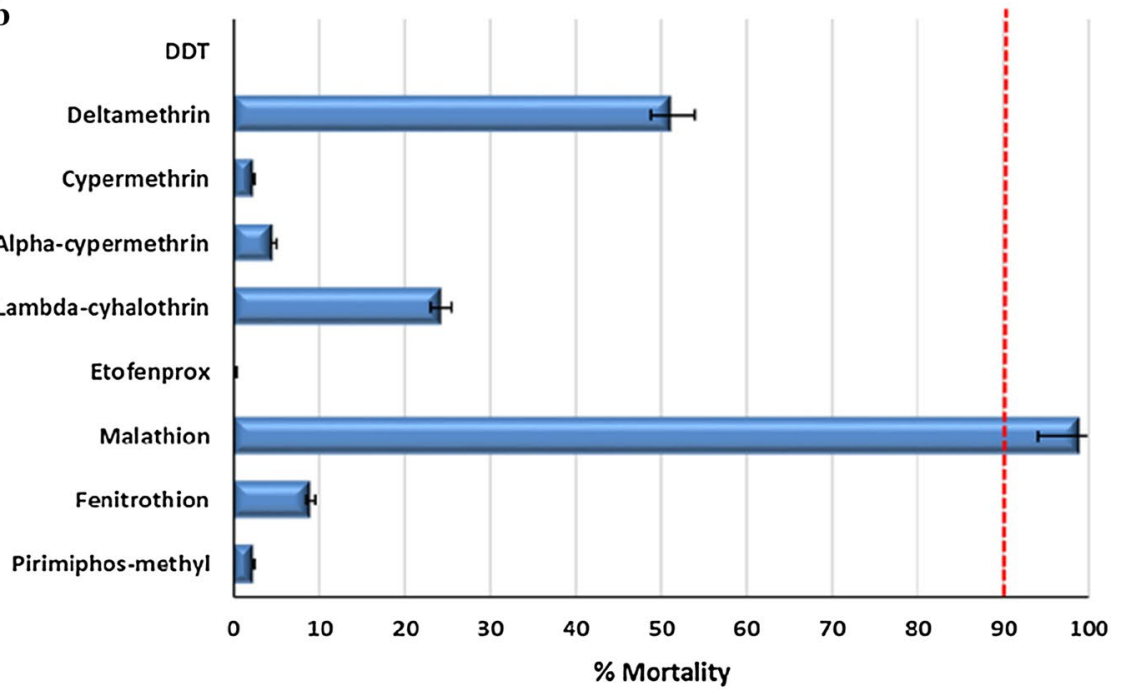

c

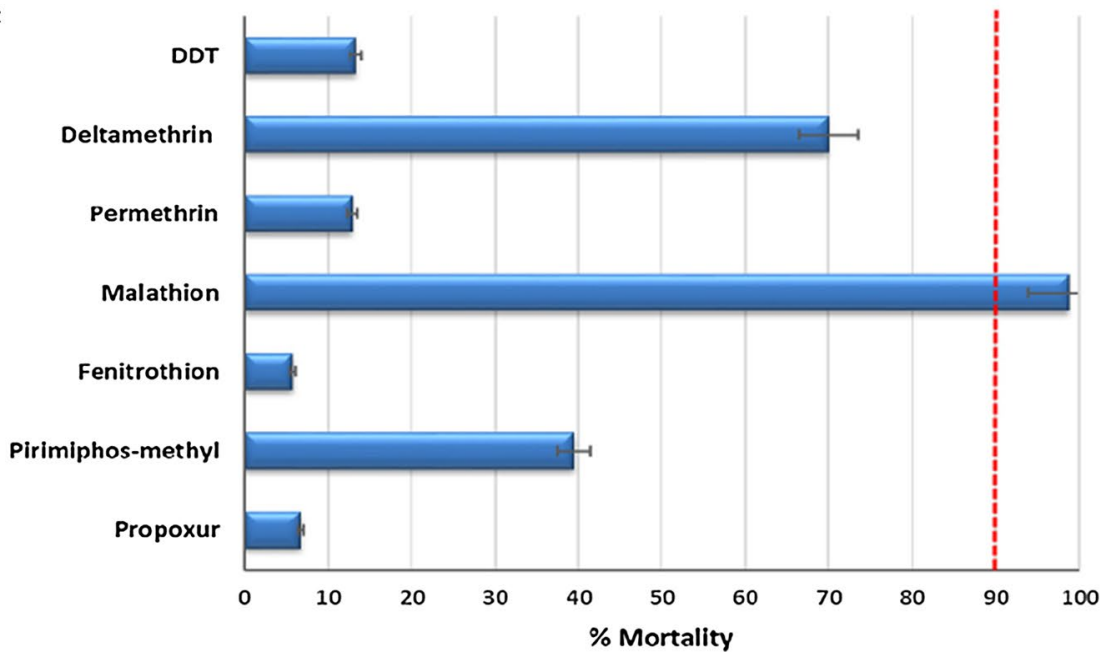

Fig. 2 Bioassay results from Peruvian Ae. aegypti from Chosica (a), Punchana (b), and Piura (c). Red dashed line shows the threshold value of $90 \%$, below which a population is considered insecticide-resistant 


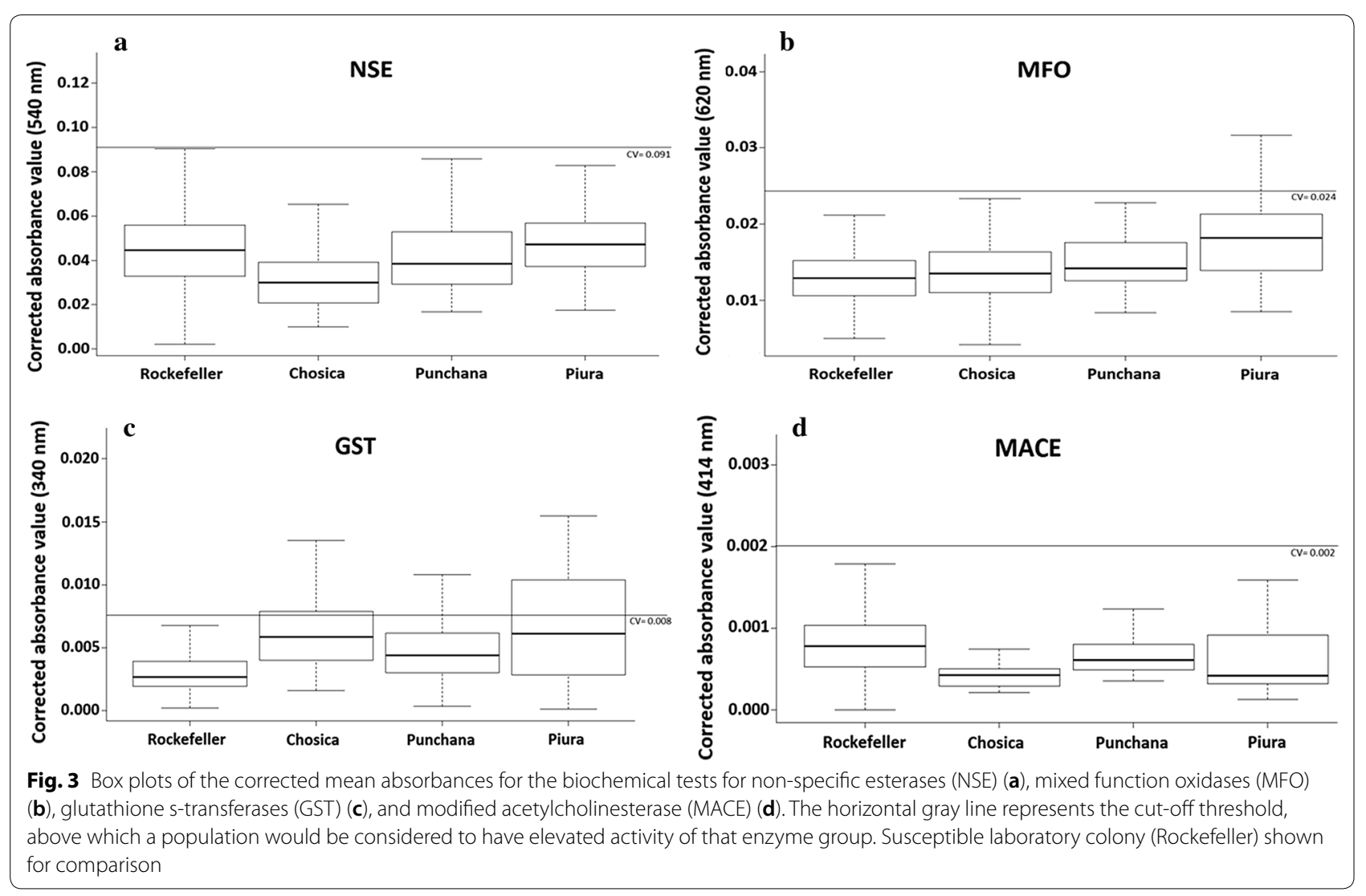

Table $3 \mathrm{~V} 1016 \mathrm{l}$ allele frequencies and genotypes by population and survivors of insecticide exposure: V, Val1016/V1016 wild type; Vl, V1016/I1016 heterozygote; and II, I1016/I1016 homozygote mutant

\begin{tabular}{|c|c|c|c|c|c|c|c|c|c|c|}
\hline \multirow[t]{2}{*}{ Population } & \multirow[t]{2}{*}{ Insecticide } & \multirow[t]{2}{*}{ Total } & \multirow[t]{2}{*}{ WV } & \multirow[t]{2}{*}{$\mathrm{Vl}$} & \multirow[t]{2}{*}{$\|$} & \multicolumn{2}{|c|}{ Allele frequency } & \multicolumn{3}{|c|}{ Genotype frequency } \\
\hline & & & & & & V1016 & 11016 & V1016/V1016 & V1016/11016 & |1016/11016 \\
\hline \multirow[t]{5}{*}{ Chosica } & Alpha-cypermethrin & 34 & 34 & 0 & 0 & 1.00 & 0.00 & 1.00 & 0.00 & 0.00 \\
\hline & Cypermethrin & 32 & 32 & 0 & 0 & 1.00 & 0.00 & 1.00 & 0.00 & 0.00 \\
\hline & Deltamethrin & 5 & 5 & 0 & 0 & 1.00 & 0.00 & 1.00 & 0.00 & 0.00 \\
\hline & Etofenprox & 35 & 35 & 0 & 0 & 1.00 & 0.00 & 1.00 & 0.00 & 0.00 \\
\hline & DDT & 31 & 31 & 0 & 0 & 1.00 & 0.00 & 1.00 & 0.00 & 0.00 \\
\hline \multirow[t]{7}{*}{ Punchana } & Alpha-cypermethrin & 33 & 7 & 16 & 10 & 0.45 & 0.55 & 0.21 & 0.48 & 0.30 \\
\hline & Cypermethrin & 33 & 5 & 13 & 15 & 0.35 & 0.65 & 0.15 & 0.39 & 0.45 \\
\hline & Deltamethrin & 37 & 1 & 19 & 17 & 0.28 & 0.72 & 0.03 & 0.51 & 0.46 \\
\hline & Etofenprox & 32 & 9 & 13 & 10 & 0.48 & 0.52 & 0.28 & 0.41 & 0.31 \\
\hline & Lambda-cyhalothrin & 33 & 5 & 18 & 10 & 0.42 & 0.58 & 0.15 & 0.55 & 0.30 \\
\hline & Permethrin & 33 & 4 & 16 & 13 & 0.36 & 0.64 & 0.12 & 0.48 & 0.39 \\
\hline & DDT & 31 & 5 & 15 & 11 & 0.40 & 0.60 & 0.16 & 0.48 & 0.35 \\
\hline \multirow[t]{7}{*}{ Piura } & Alpha-cypermethrin & 28 & 3 & 17 & 8 & 0.41 & 0.59 & 0.11 & 0.61 & 0.29 \\
\hline & Cypermethrin & 29 & 4 & 19 & 6 & 0.47 & 0.53 & 0.14 & 0.66 & 0.21 \\
\hline & Deltamethrin & 29 & 7 & 16 & 6 & 0.52 & 0.48 & 0.24 & 0.55 & 0.21 \\
\hline & Etofenprox & 30 & 7 & 19 & 4 & 0.55 & 0.45 & 0.23 & 0.63 & 0.13 \\
\hline & Lambda-cyhalothrin & 30 & 7 & 14 & 9 & 0.47 & 0.53 & 0.23 & 0.47 & 0.30 \\
\hline & Permethrin & 32 & 7 & 23 & 2 & 0.58 & 0.42 & 0.22 & 0.72 & 0.06 \\
\hline & DDT & 30 & 8 & 19 & 3 & 0.58 & 0.42 & 0.27 & 0.63 & 0.10 \\
\hline
\end{tabular}


Table 4 F1534C allele frequencies and genotypes by population and survivors of insecticide exposure: FF=F1534/F1534 wild type, FC $=$ F1534/C1534 heterozygote, CC = C1534/C1534 homozygote mutant

\begin{tabular}{|c|c|c|c|c|c|c|c|c|c|c|}
\hline \multirow[t]{2}{*}{ Population } & \multirow[t]{2}{*}{ Insecticide } & \multirow[t]{2}{*}{ Total } & \multirow[t]{2}{*}{$\mathrm{FF}$} & \multirow[t]{2}{*}{$\mathrm{FC}$} & \multirow[t]{2}{*}{$\mathrm{CC}$} & \multicolumn{2}{|c|}{ Allele frequency } & \multicolumn{3}{|c|}{ Genotype frequency } \\
\hline & & & & & & F1534 & C1534 & F1534/F1534 & F1534/C1534 & C1534/C1534 \\
\hline \multirow[t]{5}{*}{ Chosica } & Alpha-cypermethrin & 35 & 6 & 22 & 7 & 0.49 & 0.51 & 0.17 & 0.63 & 0.20 \\
\hline & Cypermethrin & 32 & 7 & 18 & 7 & 0.50 & 0.50 & 0.22 & 0.56 & 0.22 \\
\hline & Deltamethrin & 5 & 1 & 0 & 4 & 0.20 & 0.80 & 0.20 & 0.00 & 0.80 \\
\hline & Etofenprox & 35 & 7 & 23 & 5 & 0.53 & 0.47 & 0.20 & 0.66 & 0.14 \\
\hline & DDT & 31 & 5 & 18 & 8 & 0.45 & 0.55 & 0.16 & 0.58 & 0.26 \\
\hline \multirow[t]{7}{*}{ Punchana } & Alpha-cypermethrin & 33 & 0 & 0 & 33 & 0.00 & 1.00 & 0.00 & 0.00 & 1.00 \\
\hline & Cypermethrin & 33 & 0 & 0 & 33 & 0.00 & 1.00 & 0.00 & 0.00 & 1.00 \\
\hline & Deltamethrin & 37 & 0 & 0 & 37 & 0.00 & 1.00 & 0.00 & 0.00 & 1.00 \\
\hline & Etofenprox & 32 & 0 & 0 & 32 & 0.00 & 1.00 & 0.00 & 0.00 & 1.00 \\
\hline & Lambda-cyhalothrin & 33 & 0 & 0 & 33 & 0.00 & 1.00 & 0.00 & 0.00 & 1.00 \\
\hline & Permethrin & 33 & 0 & 0 & 33 & 0.00 & 1.00 & 0.00 & 0.00 & 1.00 \\
\hline & DDT & 31 & 0 & 0 & 31 & 0.00 & 1.00 & 0.00 & 0.00 & 1.00 \\
\hline \multirow[t]{7}{*}{ Piura } & Alpha-cypermethrin & 28 & 0 & 0 & 28 & 0.00 & 1.00 & 0.00 & 0.00 & 1.00 \\
\hline & Cypermethrin & 31 & 0 & 0 & 31 & 0.00 & 1.00 & 0.00 & 0.00 & 1.00 \\
\hline & Deltamethrin & 29 & 0 & 0 & 29 & 0.00 & 1.00 & 0.00 & 0.00 & 1.00 \\
\hline & Etofenprox & 30 & 0 & 0 & 30 & 0.00 & 1.00 & 0.00 & 0.00 & 1.00 \\
\hline & Lambda-cyhalothrin & 29 & 0 & 0 & 29 & 0.00 & 1.00 & 0.00 & 0.00 & 1.00 \\
\hline & Permethrin & 32 & 0 & 0 & 32 & 0.00 & 1.00 & 0.00 & 0.00 & 1.00 \\
\hline & DDT & 31 & 1 & 0 & 30 & 0.03 & 0.97 & 0.03 & 0.00 & 0.97 \\
\hline
\end{tabular}

has been reported since 1998 [17], and over the past 10 years, Ae. aegypti has demonstrated a loss of susceptibility, mainly to pyrethroids. Results from the present study of Ae. aegypti from Chosica, Punchana and Piura showed high levels of resistance to DDT, multiple pyrethroids (with the exception of deltamethrin in Chosica), and organophosphates (with the exception of malathion in Punchana and Piura). The resistance to multiple pyrethroids as well as DDT could be at least partially conferred by the $k d r$ mutations V1016I and F1534C, which were detected in individuals from these populations that survived bioassays, with the notable absence of $1016 \mathrm{I}$ in Chosica. According to Du et al. [28], several mutations on the voltage gated sodium channel gene have been associated with pyrethroid resistance in Ae. aegypti, with V1016I and F1534C having been repeatedly detected in resistant populations in the Americas. However, given that no clear patterns emerged regarding allele frequencies and survivorship to different insecticides, we cannot draw any conclusions regarding any differential contributions that the $k d r$ alleles may have in conferring resistance to the different pyrethroids tested.

Interestingly, no significant associations were found between population-level insecticide resistance phenotypes and altered activity of detoxifying enzymes as analyzed in the biochemical tests. In this regard, Muthusamy and colleagues in 2015 [29] pointed out that although biochemical tests can provide an estimate of total enzymatic activity for large enzyme groups such as oxidases, it is possible that specific P450s may be involved as resistance mechanisms and may not always be detected by biochemical tests. For example, Djouaka et al. [30] conducted a microarray analysis that suggested multiple P450 genes were involved as pyrethroid resistance mechanisms in An. gambiae despite previously collected biochemical data that had not shown elevated levels of oxidase activity. Our bioassay and $k d r$ results are comparable to those reported by Goidin et al. [31] from six sites in the Saint Martin and Guadaloupe Islands, where they also detected overexpression of several specific genes that suggested an important role in metabolic resistance, including GSTe2, CCEae3a, CYP6BB2, CYP6M11 and CYP9J23. Although on a population scale we did not detect altered enzyme activities, notable proportions of individuals from Piura (for both MFOs and GSTs) and Chosica (for GSTs) did show elevated activity, which could be an indication of resistance mechanisms stemming from a few specific genes within each of those larger enzyme families. However, further molecular analyses would be required to determine if this is the case.

High frequency of resistance to DDT was found in all three of the evaluated populations, with bioassay mortalities ranging from $0-13.3 \%$. Since DDT has not been used in Peru for vector control in over 20 years, the ongoing 
resistance could be the result of cross-resistance with pyrethroids due to shared modes of action. With respect to this finding, Bisset et al. [32], previously reported resistance to both DDT and lambda-cyhalothrin in $A e$. aegypti in Trujillo (department of La Libertad, Peru) and resistance to DDT, beta-cypermethrin, deltamethrin and lambda-cyhalothrin in a population from the city of Tumbes (Tumbes department, Peru), hypothesizing that resistance to pyrethroids could be the result of crossresistance to DDT through the $k d r$ mechanism. However, the high frequency of DDT resistance observed in our study is likely not only due to $k d r$, particularly given that in Chosica mortality to DDT was $0 \%$ yet there was a complete absence of the 1016I $k d r$ allele. Similar levels of resistance to DDT have been reported in other countries in the Americas including Colombia, Trinidad, Puerto Rico, Jamaica, Haiti, Dominican Republic, Venezuela and Suriname [33-35]. In Colombia, Fonseca et al. [33] evaluated the susceptibility status of Ae. aegypti in twelve mosquito populations and found that all populations were resistant to DDT and had elevated levels of GST activity and showed overexpression of the GSTe2 gene. Ocampo et al. [34] reported that resistance to DDT, found in populations of Ae. aegypti from 10 localities of Colombia, was genetically fixed since reinfestation occurred with populations that were already resistant to DDT. Further analyses can help to elucidate the roles that metabolic enzymes might be playing in maintaining resistance to DDT, particularly given that signs of elevated GST activity were detected in Chosica and Piura.

Although the populations of Ae. aegypti from Punchana and Piura were susceptible to malathion, the $A e$. aegypti from Chosica presented incipient resistance (94.7\% mortality). This is worrisome, given that in 2014 malathion was introduced for the widespread control of Ae. aegypti in Peru after extensive resistance to cypermethrin was detected in more than 13 regions of Peru (routine surveillance data, INS). Similarly, Yadav et al. [36] studied Stegomyia albopicta and St. aegypti in India and found general susceptibility to malathion despite its use to control mosquito-borne disease outbreaks; however, delayed knock-down values suggested that resistance to malathion was developing in the study area. In contrast, Arslan et al. [37] detected resistance to DDT, bendiocarb, permethrin and malathion in a study of Ae. aegypti and Ae. albopictus in Pakistan, despite a lack of use of organophosphates and carbamates for vector control. The authors suggested that the resistance could be due to the routine use of pesticides from these classes in agriculture in and around the study areas. This highlights the importance of monitoring vector populations for susceptibility to a broad spectrum of insecticides, as selective pressures for insecticide resistance may not always originate from public health interventions.

\section{Conclusions}

The populations of Ae. aegypti from Chosica, Piura and Punchana showed resistance to multiple classes of insecticides, with high levels of resistance to DDT, pyrethroids and organophosphates with the exception of malathion, which is one of the few remaining alternatives for the control of Ae aegypti in Peru. The mechanisms associated with this resistance included the $k d r$ mutations F1534C and V1016I, but biochemical tests did not conclusively detect elevated activity in any large detoxification enzyme families. Resistance to insecticides can threaten the efficacy of vector-borne disease control, and the results reported here highlight the importance of routine monitoring of insecticide resistance because they suggest that resistance to malathion could be developing in Peru. In this context, it is necessary to understand which alternative insecticides would be most effective for the control of Ae. aegypti and how the resistance that has already been detected can be effectively managed, especially given the ever-increasing public health burden due to Ae. aegypti-borne arboviruses in Peru.

\section{Abbreviations \\ MFOs: multi-function oxidases; GSTs: glutathione S-transferases; MACE: modi- fied acetylcholinesterase.}

\section{Acknowledgments}

We thank Edwin Requena, Norma García, Rosa Mosqueda, Ruth Quiroz, Anthony Palomino, and the rest of the technical team of the National Entomology Reference Laboratory of Peru's National Institute of Health. We also thank Máximo Lañas, Willy Natalio and José Quispe from the Piura Health Department, as well as the staff of the Villa Primavera (Chosica) Health Post, and Miguel Hernández Asto for generating the maps of the study areas.

\section{Disclaimer}

The findings and conclusions in this paper are those of the authors and do not necessarily represent the official position of the Centers for Disease Control and Prevention.

\section{Authors' contributions}

MP, JP and LMU conceived and designed the study. MP, JP and CS carried out the field work. MP, JP, LMU and KL carried out the laboratory work. MP, JP, LMU and AL analyzed and interpreted the data. JP, MP and AL wrote the manuscript. All authors read and approved the final manuscript.

\section{Funding}

Not applicable.

\section{Availability of data and materials}

All data generated or analyzed during this study are included in this published article.

Ethics approval and consent to participate

Not applicable.

Consent for publication

Not applicable. 


\section{Competing interests}

The authors declare that they have no competing interests.

\section{Author details}

${ }^{1}$ Instituto Nacional de Salud, Lima, Peru. ${ }^{2}$ Instituto Nacional de Salud-Centro de Investigación en Enfermedades Tropicales "Maxime Kuczynski"-CIETROP, lquitos, Peru. ${ }^{3}$ American Society of Microbiology, Washington, DC, USA.

${ }^{4}$ Centers for Disease Control and Prevention, Atlanta, GA, USA.

Received: 28 January 2019 Accepted: 5 October 2019

Published online: 22 October 2019

\section{References}

1. Bhatt S, Gething PW, Brady OJ, Messina JP, Farlow AW, Moyes CL, et al. The global distribution and burden of dengue. Nature. 2013;496:504-7.

2. Pan American Health Organization. Status of the Aedes aegypti eradication in the Americas. Washington, DC; 1967. Contract No.: CE56/8.

3. Schliessmann D, Calheiros L. A review of the status of yellow fever and Aedes aegypti eradication programs in the Americas. Mosq News. 1974;34:1-9.

4. Brathwaite Dick O, San Martin JL, Montoya RH, del Diego J, Zambrano B, Dayan GH. The history of dengue outbreaks in the Americas. Am J Trop Med Hyg. 2012;87:584-93.

5. Andrade CS, Caceres AG, Vaquerizo A, Ibanez-Bernal S, Cachay LS. Reappearance of Aedes aegypti (Diptera: Culicidae) in Lima, Peru. Mem Inst Oswaldo Cruz. 2001;96:657-8.

6. Cabezas C, Fiestas V, García-Mendoza M, Palomino M, Mamani E, Donaires F. Dengue en el Perú: a un cuarto de siglo de su reemergencia. Rev Peru Med Exp Salud Pública. 2015:32:146-56.

7. Ministerio de Salud, Perú. Situación epidemiológica de dengue en el Perú. Boletín Epidemiol Perú. 2018;27:540-3.

8. Hemingway J, Ranson $\mathrm{H}$. Insecticide resistance in insect vectors of human disease. Annu Rev Entomol. 2000:45:371-91.

9. Alout $\mathrm{H}$, Weill M. Amino-acid substitutions in acetylcholinesterase 1 involved in insecticide resistance in mosquitoes. Chem Biol Interact. 2008;175:138-41.

10. Ranson H, Jensen B, Vulule JM, Wang X, Hemingway J, Collins FH. Identification of a point mutation in the voltage-gated sodium channel gene of Kenyan Anopheles gambiae associated with resistance to DDT and pyrethroids. Insect Mol Biol. 2000;9:491-7.

11. Soderlund DM, Knipple DC. The molecular biology of knockdown resistance to pyrethroid insecticides. Insect Biochem Mol Biol. 2003;33:563-77.

12. Brengues C, Hawkes NJ, Chandre F, McCarroll L, Duchon S, Guillet P, et al. Pyrethroid and DDT cross-resistance in Aedes aegypti is correlated with novel mutations in the voltage-gated sodium channel gene. Med Vet Entomol. 2003;17:87-94.

13. Saavedra-Rodriguez K, Urdaneta-Marquez L, Rajatileka S, Moulton M, Flores $A E$, Fernandez-Salas I, et al. A mutation in the voltage-gated sodium channel gene associated with pyrethroid resistance in Latin American Aedes aegypti. Insect Mol Biol. 2007;16:785-98.

14. Kawada H, Higa Y, Komagata $\mathrm{O}$, Kasai S, Tomita T, Thi Yen N, et al. Widespread distribution of a newly found point mutation in voltage-gated sodium channel in pyrethroid-resistant Aedes aegypti populations in Vietnam. PLoS Negl Trop Dis. 2009;3:e527.

15. Saavedra-Rodriguez K, Maloof FV, Campbell CL, Garcia-Rejon J, Lenhart A, Penilla P, et al. Parallel evolution of vgsc mutations at domains IS6, IIS6 and IIIS6 in pyrethroid-resistant Aedes aegypti from Mexico. Sci Rep. 2018;8:6747.

16. Harris AF, Rajatileka S, Ranson H. Pyrethroid resistance in Aedes aegypti from Grand Cayman. Am J Trop Med Hyg. 2010;83:277-84.

17. Arata A, Ruebush T, Porter C, Stein J, Lounibos L, Fernandez DMD. Malaria in the Peruvian Amazon: a review of the epidemiology, entomology and insecticide resistance of vectors. Washington, DC: USAID Mission to Peru under EHP; 1999.

18. Instituto Nacional de Estadistica e Informatica. http://www.inei.gob.pe. Accessed 3 July 2019
19. Sala de Situación de Salud, Semana epidemiológica No. 52-2011. In: Epidemiología Dirección General de Epidemiología. Lima: Ministerio de Salud del Perú; 2011. http://www.dge.gob.pe/portal/index.php?optio $\mathrm{n}=$ com_content\&view=article\&id=426. Accessed 3 July 2019.

20. WHO. Test procedures for insecticide resistance monitoring in malaria vector mosquitoes. Geneva: World Health Organization; 2013.

21. The MR4 Methods in Anopheles Research Laboratoty Manual, 4 ed; 2014. https://www.beiresources.org/Publications/MethodsinAnophelesResearc h.aspx. Accessed 3 July 2019.

22. Brogdon WG. Microassay of acetylcholinesterase activity in small portions of single mosquito homogenates. Comp Biochem Physiol C. 1988;90:145-50.

23. Brogdon WG, Beach RF, Stewart JM, Castanaza L. Microplate assay analysis of the distribution of organophosphate and carbamate resistance in Guatemalan Anopheles albimanus. Bull World Health Organ. 1988;66:339-46.

24. Brogdon WG, Hobbs JH, St Jean Y, Jacques JR, Charles LB. Microplate assay analysis of reduced fenitrothion susceptibility in Haitian Anopheles albimanus. J Am Mosq Control Assoc. 1988;4:152-8.

25. Brogdon WG. Mosquito protein microassay. I. Protein determinations from small portions of single-mosquito homogenates. Comp Biochem Physiol B. 1984;79:457-9.

26. Brogdon WG. Mosquito protein microassay. II. Modification for potential field use. Comp Biochem Physiol B. 1984;79:461-4.

27. Yanola J, Somboon P, Walton C, Nachaiwieng W, Somwang P, Prapanthadara LA. High-throughput assays for detection of the F1534C mutation in the voltage-gated sodium channel gene in permethrin-resistant Aedes aegypti and the distribution of this mutation throughout Thailand. Trop Med Int Health. 2011;16:501-9.

28. Du Y, Nomura Y, Zhorov BS, Dong K. Sodium channel mutations and pyrethroid resistance in Aedes aegypti. Insects. 2016;7:E60.

29. Muthusamy R, Shivakumar MS. Involvement of metabolic resistance and F1534C kdr mutation in the pyrethroid resistance mechanisms of Aedes aegypti in India. Acta Trop. 2015;148:137-41.

30. Djouaka RF, Bakare AA, Coulibaly ON, Akogbeto MC, Ranson H, Hemingway J, et al. Expression of the cytochrome P450s, CYP6P3 and CYP6M2 are significantly elevated in multiple pyrethroid-resistant populations of Anopheles gambiae s.s. from southern Benin and Nigeria. BMC Genomics. 2008;9:538.

31. Goindin D, Delannay C, Gelasse A, Ramdini C, Gaude T, Faucon F, et al. Levels of insecticide resistance to deltamethrin, malathion, and temephos, and associated mechanisms in Aedes aegypti mosquitoes from the Guadeloupe and Saint Martin islands (French West Indies). Infect Dis Poverty. 2017;6:38.

32. Bisset JA, Rodriguez M, Fernandez D, Palomino M. Insecticide resistance mechanisms of Aedes aegypti (Diptera: Culicidae) from two Peruvian provinces. Rev Cubana Med Trop. 2007;59:202-8.

33. Fonseca-Gonzalez I, Quinones ML, Lenhart A, Brogdon WG. Insecticide resistance status of Aedes aegypti (L.) from Colombia. Pest Manag Sci. 2011:67:430-7.

34. Ocampo CB, Salazar-Terreros MJ, Mina NJ, McAllister J, Brogdon W. Insecticide resistance status of Aedes aegypti in 10 localities in Colombia. Acta Trop. 2011;118:37-44.

35. Ardila-Roldan S, Santacoloma L, Brochero H. Status of insecticide susceptibility of public health use in natural populations of Aedes aegypti (Diptera: Culicidae) of Casanare. Colombia. Biomedica. 2013;33:446-58.

36. Yadav K, Rabha B, Dhiman S, Veer V. Multi-insecticide susceptibility evaluation of dengue vectors Stegomyia albopicta and St. aegypti in Assam, India. Parasit Vectors. 2015:8:143.

37. Arslan A, Rathor HR, Mukhtar MU, Mushtaq S, Bhatti A, Asif M, et al. Spatial distribution and insecticide susceptibility status of Aedes aegypti and Aedes albopictus in dengue affected urban areas of Rawalpindi, Pakistan. J Vector Borne Dis. 2016;53:136-43.

\section{Publisher's Note}

Springer Nature remains neutral with regard to jurisdictional claims in published maps and institutional affiliations. 